\title{
A Study on Academic Stress Among Different Categories of Students - A Literature Review
}

\author{
L.Vijayashree, Shishira Srinivasa
}

\begin{abstract}
Stress is certainly a great term, but it can be dealt with smaller modifications that we add to our everyday lives. The stress is mostly prevalent among government officers, managers, politicians, house-wives and teachers. It is necessary to recognize the cause of stress in order to deal with it. Effective and meticulous interventions can be outlined. Stress is still considered subjective process and encompass the personal analysis of the individual and counteract a threatening incident. Stress may lead to depression, anxiety and many others. The rise of number of stress management seminars, numerous articles written, studies etc. suggest the escalation in the past few stress-related cases decades. This study addresses the conceptual structure of stress between stress causes Students and how tension is handled. It also presents a literature review on the subject.
\end{abstract}

Keywords: Stress, Students, Causes of Student Tension, Management of Stress

\section{INTRODUCTION}

Stress is a mental or physical feeling of tension. A variety of accidents occur in the life of a person which leads to negative emotions such as anger, frustration and nervousness. Stress is the body's response to demand or threat. It could be positive at times; however chronic stress can lead to severe health. Stress levels can vary depending on how you react to a certain situation. Certain citizens don't care and don't worry; they consider stress to be meaningless knock and live on. In reality, some worry more than they should and affect their health.

Stress is regarded as a negative, behavioural, physiological mechanism when the person attempts to adapt or compromise stressors (Bernstein et al. 2008). Stressors are the most circumstances that disturb or threaten to disrupt the functioning of individuals on a daily basis.

Citizens to make improvements" people (Auerbach and Grambling,1998) Malach, Pines and Keinan (2007) have described stress as an insight into incongruity.

The environmental pressure (stressors) and the capacity of the individual to meet these requirements. Auerbach \& Auerbach Grambling (1998) found any condition that could stimulate threats or dangers of any sort Wellness can be seen as tension.

Manuscript received on April 07, 2021.

Revised Manuscript received on April 13, 2021.

Manuscript published on April 30, 2021.

* Correspondence Author

Ms. Shishira Srinivasa*, Management, BNM Institute of Technology, Bangalore, India. Email: shishibenbarnes@gmail.com

Dr. L.Vijayashree, Professor - MBA Dept., Head-Entrepreneurship Development Cell- BNMIT, Chief- Coordinator- New Gen IEDC, DST, GoI, BNMIT. Bangalore. Email: Professor.bnmit@gmail.com

(c) The Authors. Published by Blue Eyes Intelligence Engineering and Sciences Publication (BEIESP). This is an open access article under the CC BY-NC-ND license (http://creativecommons.org/licenses/by-nc-nd/4.0/)

\section{CAUSES OF STUDENT TENSION}

Academic pressure has risen in recent years, tests and assignments have taken place and a lot of other things a student has to do. The architecture, but also the teachers and parents have placed a lot of pressure on the students to obtain good grades. These expectations make the students work intensely and generate more tension. With Students, academics, parents and organisations want students to attend extracurricular activities too, students' present aspirations can be an all-rounder. This demanding conduct of parents and teachers leave the students confused and pressures.

An important role in shaping the personality and life outlook of a child. Social pressure is also Another popular word you hear from the adolescents. This might place pressure on someone else, the list is exhaustive, drink, smoke, cheat on the exam, lying, etc. The burden of peers can be detrimental and Compelling. It can help form the personalities for introverted students or pose as a barrier and trigger tension. It is very necessary for students to have information and surround yourself with positive people in order to make the majority of social influences positive.

Heavy workloads and the impression that you still run to meet others and deadline could be terrible. Parental pressure on children to shine and do well in their study. It is exceptionally high in extracurricular activities. It is necessary to excel in studies, often susceptible to violence, harms morality and is one of the main causes of stress, failure and breakdown. The race between parents to show their child is all-round and ends rather than successful, up as a victim. Lack of support for students is a significant cause of stress, the lack of contact with parents and teachers tends to build on suspicions and confusions, this may ultimately have induced stress in the child. A child is supposed to achieve a lot, yet they feel lost at sea and are left directionless because of lack of proper assistance.

Long-term stress can lead to physical and emotional disorders and lead to anxiety and depression. A channel is necessary to alleviate the anxiety. (2000) Mckean et al. believed the stressors are not the only cause for anxiety, tension or depression, but rather synergy stress creates stress between stressors and the approach and attitude of the individual to these stressors. Though stress is always considered evil, but the other side of the coin is still there. The right kind of stress helps to sharpen the mind and reflexes, helping to improve the memory.

Moderate stress is always necessary to function efficiently and effectively. It will help you face everyday challenges and may inspire students to achieve their objectives.

Published By:

Blue Eyes Intelligence Engineering

\& Sciences Publication

(C) Copyright: All rights reserved. 


\section{STRESS MANAGEMENT}

\section{Stress Management} young people. Study of NYU claims that a great many high school students struggle during school years and the stressful baggage is brought to college years leading to academic dissolution and can lead to Problems in mental health. When the student eventually arrives at college, he has to deal with the stress of new and improved workload, pressure to make friends and to be social, Appropriate circle, a far more daunting network, all without the Parents' support on several occasions. It is also incredibly necessary to learn to deal with Stress, so that students can learn to navigate and sail across the seas.

There are different ways and means in which students can adopt stress relief, such as absorption in A regular exercise form, this small change will go a long way and ensures a sustainable happiness climate. Meditation and breathing should also be performed be integrated during exams to alleviate stress and prevent panicking for students. It will enable students to be more patient and to ensure that students have adequate sleep and have better graph learning. Whether played under stress or otherwise, music is therapeutic. Hearing music can reap many benefits and tension can definitely subside. The way you talk about yourself and the attitude makes a huge difference, so positive self-talk is necessary and will continue to conduct to a harmonious atmosphere.

\section{LITERATURE REVIEW}

In their research, Reddy et al. (2018) concluded that there is a wise stream difference in stress among students. Stress at the personal, social and institutional levels is critical. Settlements, feedback, yoga, teaching in life skills, attention to detail, meditation and psychotherapy are

found to be useful techniques for stress management. The trick to coping with stress is to recognise the root cause of stress. Professionals should develop personalized stress management techniques. The integrated health of the students is not only important to the participant but also to the institute.

In his research Dimitrov (2017) stated that stress could be tackled by ensuring that students offer their wellbeing utmost importance. Food, training, job, leisure is some of the areas where focus on. He also concluded that the system of education is more connected to the university qualifications and does not adequately lead to students' holistic growth.

Students are generally conditioned so that they are afraid to start challenges as the emphasis is only on academics and not the psychological growth. There are not many options for the education medium. English is the only available alternative that can act as an impediment for rural students. Not many courses are available accessible that are eccentric to jobs. New graduates need more expertise in communication and acts as better investment growth.

The links between academic stress and mental health have been shown by Subramani and Kadhiravan (2017) between students. He supported the correlation between academic stress and mental health and the academic structure is tight for students. Parents and schools placed pressure on their students too much for the higher grades, which discourages the applicants, to be added, sufficient guidance help from parents and colleges. The students are minded healthy as they
Stress can be stressful and can lead to depression in many

perform in academic fora constructively. They also proposed that private school students are more stressed compared to government students' schools due to overwork and other associated academic activities. Meaningful difference was noticed in the mental health of students from public and private schools. He stated that private school students had a particular treatment and comprehensive exposure in contrast to students in government schools of poor socio-economic history and absence of exposure. This is one of the causes for stress escalation.

In their research Sharma et al. (2016) suggested the use of different approaches to minimize stress. Doing one thing regular physical activity can resolve stress issues. Various may also be implemented time management strategies and recreational opportunities that can support students. Modification in the teacher delivery style ends and mentors will provide the teaching with fresh air.

Prabu (2015) observed secondary students and indicated that they were male students stressed more than women's students. The academic burden of urban students is greater than rural stress

Students. Stress of government school students is lower than stress of private school students.

Science stream students were found to be more depressed than Arts students.

Deb et al. (2014) researched in Kolkata on 400 male schoolchildren from five high schools who studied in the 10th and 12th grades. 35\% of students have high academic qualifications Stress and 37 percent displayed high levels of anxiety. Students of marginal qualifications it is said to have a higher stress level than students with higher levels. Participants in extracurricular activities have been noted to be stressed more as regards these students who haven't been involved.

Kaur (2014) accepted that adolescent mental health is impaired by the academic Stress. Girls with academic pressures have poor mental well-being relative to Boys. The study showed that parents often placed pressure and stress on students. This leads to mental health decline.

In his research, Bataineh (2013) assessed the academic stressors faced by students of University. The results of the analyses indicate that academic overload is unacceptable, not enough time to research due to the broad content and high expectations of the family Low levels of motivation and stress are some of the causes. Fear of failure is also the most important thing stress explanation. There was no substantial difference between the students of different Specializations.

Khan and Kausar (2013) concluded that stress certainly affects academic achievement negative way, although there were no major gender gaps. The gap has been between junior and senior pupils, clear. Stress definitely affects the ability to learn effectively and time management. And time management. Daily study is necessary to reduce academic pressure.

Busari (2012) found that stress among secondary school students contributed to depression and is related to the effect on academic results. Introduction of prevention and instruction Competencies and other coping strategies should be taken seriously. 
Stress among professional students was studied by Nandamuri and Gowthami(2011) and Curriculum and criteria of directions were the most responsible for stress with 86 percent, followed by 63 per cent for problems relating to placement, evaluation and team work. The estimates were microphones stress issues, and 12 sub-problems related to curriculum and training are mentioned. When the sub-problems of each parameter are established, the academic has enhanced his vision administrators to initiate efforts to minimize student stress severity.

Stress has become an important subject in academic circles, according to Agolla (2009). Many Philosophers conducted considerable stress research and concluded that this subject is required more attention.

Radcliff and Lester (2003) analysed last year's predicted stress student undergraduates and recognised classrooms, inadequate instruction, pressure. The reasons for the tension to build up were to combine and be linked.

McKean and others (2000) argue that undergraduate students experience greater stress each semester at anticipated times. Academic obligations, financial burdens and the lack of time management abilities contribute to growth up of stress. Excessive stress can affect well-being, emotion and academic perception.

\section{CONCLUSION}

The students are primarily stressed by the inadequacy of proper support. There is a default

assessment procedure that does not offer sufficient scope to experiment and drive students

Excellence limits. There are many personal and social factors that contribute to stress

Students. Students. Lack of clarification and unavailability of right career consultants contribute to unidirectional objectives, and even after they graduate, students become clueless and vulnerable in their jobs and help them achieve their goals. Research stresses for academics, extracurricular sports, duties etc. developed beyond compare. Parents expect their children to engage in the rat race and to raise the social standing of their own in society, outshine their rivals. In this age of cutting throat rivalry, the latest fad is running behind numbers, sad reality but true. Each child is different, so it is important for parents to get their children to realize the value of recognizing their forces and motivating them to pursue a career in the field of their skill of their ability. It is important to do what you want or love.

\section{REFERENCES}

1. Busari,A.O. (2012). Evaluating the Relationship between Gender, Age, Depression and Academic Performance among Secondary School Students, International Journal of Interdisciplinary and Multidisciplinary Studies, 4(2), 6-12

2. Bataineh.M.Z (2013). Academic stress among undergraduate students: the case of education faculty at King Saud University, International Interdisciplinary Journal of Education, 2(1), 82-88.

3. Bernstein, D.A, Penner, L.A, Stewart, A.C. and Roy, E.J. (2008). Psychology (8th edition), Houghton Mifflin Company Boston New York.

4. Deb, Sibnath, Esben,S., and Jiandong,S. (2014). Academic-related stress among private secondary school students in India, Asian Education and Development Studies, 3(2), 118-134.

5. Dimitrov.G (2017). A study on the impact of Academic Stress among college students in India, Ideal Research. 2(4) $41 \%$ and $24 \%$ respectively. The analysis also found multiple

6. Kaur,S. (2014). Impact of Academic Stress on Mental Health: A Study of School going Adolescents, Global Journal for Research Analysis, 3(4)

7. Khan,M.J. and Altaf, S. Kausar,H.(2013). Effect of Perceived Academic Stress on Students' Performance, FWU Journal of Social Sciences, 7(2), 146-151

8. Malach-Pines A and Keinan G (2007). Stress and burnout in Israel police officers during Palestinian uprising (intifada), International Journal of Stress Management, 14,160-174.

9. McKean,M.,Misra, R.,West, S, and Tony , R.( 2000).College Students' Academic Stress and Its relation to Their Anxiety, Time Management, and Leisure Satisfaction. American Journal of Health Studies, 16, 41-51

10. Prabu Suresh P (2015). A study on academic stress among higher secondary stress, International Journal of Humanities and Social Science Invention, 4(10), 63-68

11. Nandamuri, P.P. and Gowthami, Ch.(2011). Sources of Academic Stress-A Study on Management Students, Journal of Management and Science,1(2), 31-42

12. Radcliff, C. and Lester, H.(2003). Undergraduate medical Education. Perceived Stress during undergraduate medical training, A qualitative study. Medical Education, 37(1), 32-38

\section{AUTHORS PROFILE}

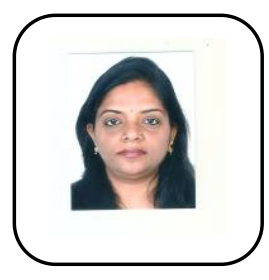

Dr. L. Vijayashree, Experience:

- Head-Entrepreneurship Development CellBNMIT and Chief- Coordinator- New Gen IEDC, DST, GoI, from 2017.

- Head and Professor of MBA - 3 Years, Academic experience in total -17 years, Industry experience - 4 years.

Journals \& book's Publication: 56 International Journal Paper and National Research papers (citation factor- 75). Also presented Research papers and won outstanding paper awards in International conferences held abroad and in India.

Published Books for undergraduate students in the areas of Business Environment, Organizational Behavior and Strategic Management.

Grants: Chief coordinator-Entrepreneurship Development Cell at BNMIT received many grants as Principal Investigator for the following Department of Science and Technology (DST) projects:

1. DST - NewGen IEDC (Innovation Entrepreneurship Development Cell) 2017- 2022 -

INR 2, 87, 50,000/- for students project prototype development.

2. DST - NIMAT(National Implementing and Monitoring Agency for Training) Project 2018 - 2019 -

INR. 2, 00, 000/- for 10 Entrepreneurship Awareness Camp.

3. DST - NIMAT(National Implementing and Monitoring Agency for Training) Project 2017 - 2018 -

INR. 1, 00, 000/- for 5 Entrepreneurship Awareness Camp.

4. DST - NIMAT(National Implementing and Monitoring Agency for Training) Project 2015 - 2016 -

IINR 40, 000/- for 2 Entrepreneurship Awareness Camp.

PhD Guidance: Three of the $\mathrm{PhD}$ research scholars are awarded Doctorate under VTU and two are in the verge of submitting their final thesis in the areas of Stress, E-Governance and change management, Leadership, Role Efficacy and Locus of control areas.

Journal Editorial Boards: AMC Indian Journal of Entrepreneurship, Member of scientific Technical committee and editorial Board on Arts Management and social sciences assisted by King Mongkut's University of Technology Thonburi, Thailand, Advisory editor of Mustang Journal of Law and Legal Studies, USA, Editorial Board Member for International Journal of Social Science Research, USA, Indian Journal of Entrepreneurship, Reviewers committee in International Journal of Human Resource management, FOREX -Technical Journal, CMS Journal of Management -India.

\section{Published By:}

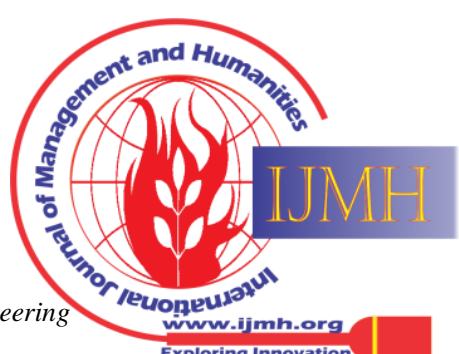

\& Sciences Publication

(C) Copyright: All rights reserved. 
Shishira Srinivasa,

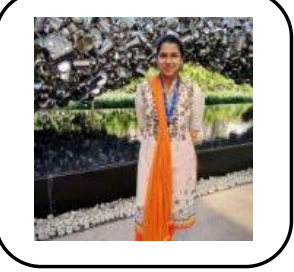

1. Part time Phd Research Scholar at BNMIT, Affiliated to VTU, Belagavi,

2. Currently working as a Senior Tax Consultant for US taxation at KPMG Global Services

3. Has published more than 8 articles on stress management in various National and International Journals

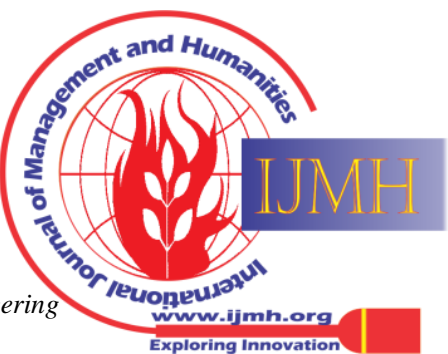

